\title{
Platelet Count and Its Prognostic Value in Pregnancy Induced Hypertension
}

\author{
Sharma $\mathrm{N}^{1}$, Kumari $\mathrm{S}^{2}, \mathrm{BC} \mathrm{D}^{1}$, Shrestha $\mathrm{M}^{3}$
}

\section{ABSTRACT}

Introduction: Hypertensive disorders of pregnancy is one of the maternal diseases that cause the most detrimental effects to the mother and the fetus. ${ }^{1}$ It is the leading cause of direct maternal death along with hemorrhage and infections. Approximately $70 \%$ of hypertensive disorders are due to gestational hypertension, preeclampsia and eclampsia whereas other $30 \%$ are due to preexisting or undiagnosed hypertension. ${ }^{2}$ Out of all the hematological abnormalities that occur in PIH, thrombocytopenia is the most common seen to occur in $11 \%$ to $29 \%$ of patients. ${ }^{3}$ Thrombocytopenia occurs more commonly in patients with eclampsia (30\%) compared to patients with both mild and severe forms of pre-eclampsia (15\%-18\%). ${ }^{4}$ Aims :To find out the severity of disease with platelet count in pregnancy induced hypertension. Methods: This is a hospital- based descriptive cross sectional study, conducted in the department of Obstetrics and Gynecology at Nepalgunj Medical College Teaching Hospital, Kohalpur, Banke, Nepal, conducted over a period of one year from September 2018 to August 2019. Fifty pregnant women were enrolled in study after getting informed written consent and assessing for inclusion and exclusion criteria. Results: Incidence of Pre-eclampsia/eclampsia is $2.3 \%$ in this study. Majority of the women belong to age group 21-25(40\%), followed by $15-20(38 \%)$ with mean age $23.18 \pm 5.45$. $62 \%$ constituted primigravidas and $38 \%$ were multigravidas. 33 (66\%) cases were at term (37-42 weeks of gestation), 11(22\%) at 34-36 weeks of gestation and $6(12 \%)$ were at $28-33$ weeks of gestation with mean gestational age $36.38 \pm 3.17$. Eclampsia cases were found more i.e. $48 \%$, followed by pre-eclampsia $38 \%$ and Gestational hypertension $14 \%$. Moderately low platelet count was seen in $11.76 \%$ of Gestational hypertension, $47 \%$ of pre-eclampsia and $41.17 \%$ of eclampsia and severely low platelet count in $21.4 \%$ pre-eclampsia and $64.70 \%$ of eclampsia. Conclusion: PIH continues to be a leading cause of Maternal and perinatal morbidity and Mortality. The disease accounts of 40,000 maternal deaths worldwide per year ${ }^{5}$. It is one of the common causes of iatrogenic preterm delivery. Etiology of Pre-eclampsia/Eclampsia is complex and not completely understood. A combination of abnormal Placentation and predisposing maternal factor contribute to widespread endothelial dysfunctions which lead to the syndrome of PIH. To date there has been no screening test that has been widely adopted in clinical practice. Platelet estimation method is reliable, rapid, cheaper, and simple lab method. Prognosis of diseases could be monitored by measuring platelet count and level of platelet count can predict the severity of PIH. Therefore assessment of platelet count has special place in management of PIH.

\section{Keywords: Eclampsia, Preeclampsia, Thrombocytopenia}

\section{Authors:}

1. Dr. Nirmala Sharma

2. Dr. Sheela Kumari

3. Dr. Durga BC

4. Dr. Merina Shrestha

${ }^{1}$ Department of Obstetrics \& Gynaecology, Nepalgunj Medical College \& Teaching Hospital, Kohalpur, Banke

2 Department of Obstetrics \& Gynaecology, Lumbini Provincial Hospital, Lumbini, Rupandehi

${ }^{3}$ Department of Community Medicine, Nepalgunj Medical College and Teaching Hospital, Kohalpur, Banke

\section{Address for Correspondence:}

\author{
Dr. Nirmala Sharma \\ Department of Obstetrics \& Gynecology \\ Nepalgunj Medical College and Teaching Hospital \\ Kohalpur, Banke, Nepal \\ Email: sapkota_neerusha@yahoo.com
}

\section{INTRODUCTION}

According to the WHO systemic review on maternal mortality worldwide, hypertensive disease remains a leading cause of direct maternal mortality, together with hemorrhage and infections; hypertension forms the deadly triad that contributes to morbidity and mortality during pregnancy and childbirth. ${ }^{6}$
This hypertensive disorder in pregnancy is known as pregnancy induced hypertension is defined as a sustained systolic blood pressure of $140 \mathrm{~mm}$ of $\mathrm{Hg}$ or more and a diastolic blood pressure of $90 \mathrm{~mm}$ of $\mathrm{Hg}$ or more for the first time after 20 weeks of gestation and disappear following delivery. ${ }^{7} \mathrm{PIH}$ is responsible for $14 \%$ of maternal deaths in the world. ${ }^{8}$ The incidence of pregnancy induced hypertension is between ( 6 to 
$15) \%$ in primigravidas and ( 2 to 4$) \%$ in multigravidas. Whereas incidence of preeclampsia is (5 to 7) \% and eclampsia is ( 0.5 to 2$) \%$ of all pregnancies. The condition is more frequent in obese women and in women with multiple gestation, diabetes, chronic hypertension and previous history of preeclampsia. ${ }^{9}$

Pregnancy-induced Hypertension (PIH) is a syndrome of hypertension with proteinuria (Pre-eclampsia) or without proteinuria and edema, with the clinical manifestation usually occurring late in pregnancy and regressing after delivery of the conceptus. ${ }^{10}$ Platelets are also called Thrombocytes, are a component of blood whose function is to stop bleeding by clumping and clotting blood vessel injuries. ${ }^{11} \mathrm{~A}$ normal platelet count in a healthy individual is between 150,000 and 450,000 per $\mu \mathrm{l}$ (microliter) of blood (150-450 × 10\%/L). Ninety-five percent of healthy people will have platelet counts within this range. ${ }^{12}$ In the pregnant women, thrombocytopenia is defined as a platelet count of less than $150 \times 10^{9} / \mathrm{L}$. Counts of 100 $150 \times 10^{9} / \mathrm{L}$ are defined as mild thrombocytopenia and counts of $50-100 \times 10^{9} / \mathrm{L}$ as moderate thrombocytopenia, while counts of less than $50 \times 10^{9} / \mathrm{L}$ known as severe thrombocytopenia. Either the decreased production or the increased destruction via any means causes thrombocytopenia. In pregnancy, increased platelet destruction may be mediated by immunological mechanisms, abnormal platelet activation, or platelet consumption. ${ }^{13}$

Out of all the hematological abnormalities that occur in PIH, thrombocytopenia is the most common seen to occur in $11 \%$ to $29 \%$ of patients. ${ }^{14}$ Thrombocytopenia occurs more commonly in patients with eclampsia (30\%) compared to patients with both mild and severe forms of pre-eclampsia (15\%-18\%). ${ }^{15}$

Lower the platelet count, greater are maternal and fetal morbidity and mortality. ${ }^{7}$ It is found that thrombocytopenia increases the risk of perinatal complications such as abruptio placenta, preterm delivery, low Apgar score and stillbirth. ${ }^{35}$ The degree of thrombocytopenia increases with severity of disease and the incidence of thrombocytopenia depends on the severity of the disease process. ${ }^{20}$ Lower the platelet count, greater are maternal and fetal morbidity and mortality. ${ }^{4}$ Overt thrombocytopenia, defined by platelet count $<1$ lakh/ $\mu l$ indicates severity of diseases process where in most cases delivery is indicated because platelet number continues to decrease after that. ${ }^{1}$ HELLP Syndrome ( Hemolysis, Elevated Liver enzyme i.e. bilirubin $>1.2 \mathrm{mg} / \mathrm{dl} \mathrm{LDH}>600 \mathrm{U} / \mathrm{L}$, Serum AST $>70 \mathrm{U} / \mathrm{L}$ and Low Platelet count $<1 \mathrm{Lakh} / \mu \mathrm{l}$ ) show poor fetal outcome and occurs in $2 \%-12 \%$ women with severe pre- eclampsia or eclampsia . ${ }^{16,1}$ Inadequate cytotrophoblast invasion that occurs in pre-eclampsia may constitute the impetus to endothelial cell dysfunction and increased activation of platelets. There is increased platelets consumption because of uncontrolled intravascular platelets activation and fibrin deposition in hypertension in pregnancy. ${ }^{36,37}$ The contact of platelets with the injured endothelium may represent the initial step of a coagulation cascade which leads to increased consumption of platelets in the utero placental circulation with resultant reduction in the number of circulating platelets in the first phase of the process. Subsequently, there may be a compensatory increase in bone marrow production. In fact, there is evidence that in $\mathrm{PIH}$, the platelets production time is significantly reduced in comparison with normal pregnancies; Young platelets thrown in circulation are bigger and present a higher tendency to aggregation. ${ }^{17,18}$

\section{METHODS}

This is a hospital based descriptive cross sectional study. Sample was taken by convenient sampling method till desired size reached. Fifty pregnant women were enrolled in the study. This study was conducted in the department of Obstetrics and Gynecology at Nepalgunj Medical College Teaching Hospital, Kohalpur, Banke, Nepal, over a period of one year, September 2018 to August 2019. Pregnant women, primigravidas and multigravidas visiting Department of Obstetrics and Gynecology or Labor room after 20 weeks of gestation, may or may not be in labour with history of hypertension i.e. systolic $\mathrm{BP} \geq 140 \mathrm{~mm}$ of $\mathrm{Hg}$ and diastolic $\mathrm{BP} \geq 90 \mathrm{~mm}$ of $\mathrm{Hg}$ were enrolled after getting informed written consent and assessing for inclusion and exclusion criteria. A detail history was taken regarding chief complaint, history of present and past illness, family history, personal history, menstrual history, obstetrics history, contraceptive history. A thorough general examination with reference to pulse, BP, Temperature, Respiratory Rate followed by systemic examination included CVS, Respiratory, Per Abdominal and Per Vaginal examination was done. All the routine ANC investigations i.e. $\mathrm{Hb} \%$, blood grouping and $\mathrm{Rh}$ typing, RBS, HBsAg, HIV, VDRL, Routine Urine, Urine Albumin, $24 \mathrm{hr}$. urine protein monitoring, $\mathrm{BT}, \mathrm{CT}, \mathrm{PT}, \mathrm{INR}, \mathrm{RFT}$, LFT, platelet count by automated hematology analyzer and by Peripheral Blood Smear and Ultrasonography for obstetrics scan for fetal assessment as well as abdominal pelvic scan was done to rule out other causes of hypertension. OPD patient was regularly followed up till delivery, in each ANC visit where BP, platelet count was monitored. All the collected data were entered in Microsoft Office Excel worksheet. The statistical analysis was done after consultation with expert statistician advice using Statistical Package for Social Science (SPSS) version 20. The level for significance was set as $p<0.05$. The statistical test significance (chi square) was applied to find $p$ value and relevant other tests were also used whenever required. $p$ $<0.05$ was considered statistically significant.

\section{Inclusion criteria:}

All pregnant women, both primigravidas and multigravidas, may or may not be in labour, with hypertension of Pregnancy after 20 weeks of pregnancy visiting department of Obstetrics and Gynecology. 


\section{Exclusion criteria:}

1. Previous history of hypertension

2. Previous history of Diabetes mellitus

3. Previous history of renal disease

4. Previous history of thyroid disorder

5. Any type of anemia

6. Taking any medications which can affect platelet count and cause bone marrow depression except for vitamins, iron and calcium

\section{RESULTS}

The age of the women, in this study majority of the women belong to age group 21-25(40\%) followed by $15-20$ (38\%) with mean age $23.18 \pm 5.45$ (Fig 1 )

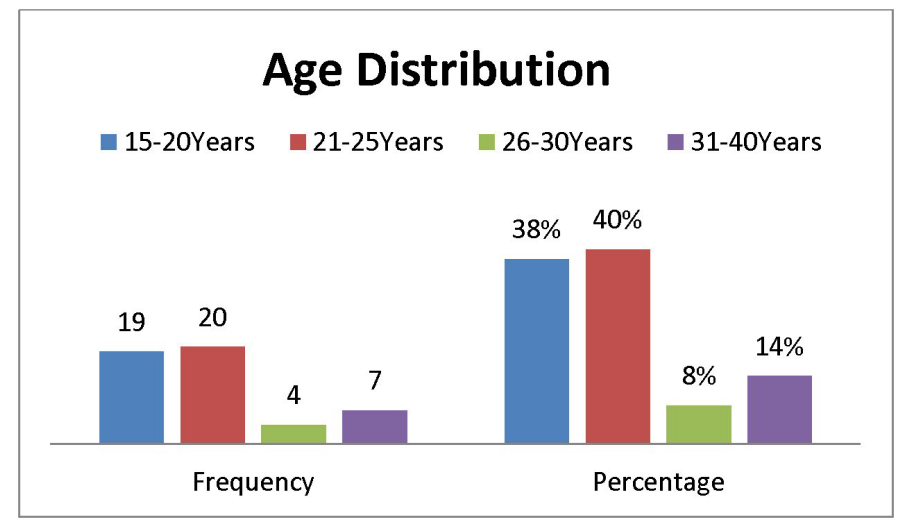

Figure 1

\section{Gravidity:}

In this study maximum number of women $62 \%$ constituted primigravidas only $38 \%$ were multigravidas.

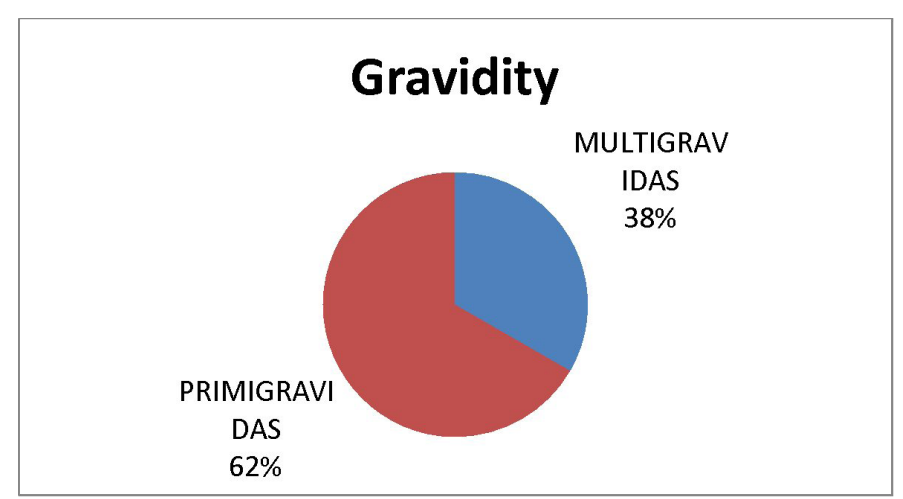

Figure 2

\section{Gestational Age:}

In this study, out of 50 cases 33 (66\%) cases were at term (37-42 weeks of gestation), $11(22 \%)$ at $34-36$ weeks of gestation and $6(12 \%)$ are at $28-33$ weeks of gestation with mean gestational age is $36.38 \pm 3.17$ as shown in figure 3 .

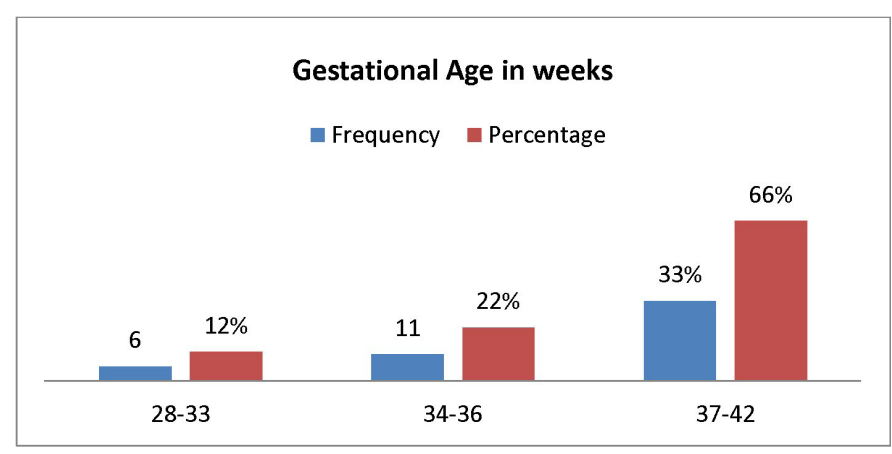

Figure 3

\section{Pregnancy Induced Hypertension}

In this study, eclampsia cases were found more i.e. $48 \%$ followed by pre-eclampsia $38 \%$ and Gestational hypertension $14 \%$ as shown in fig 4

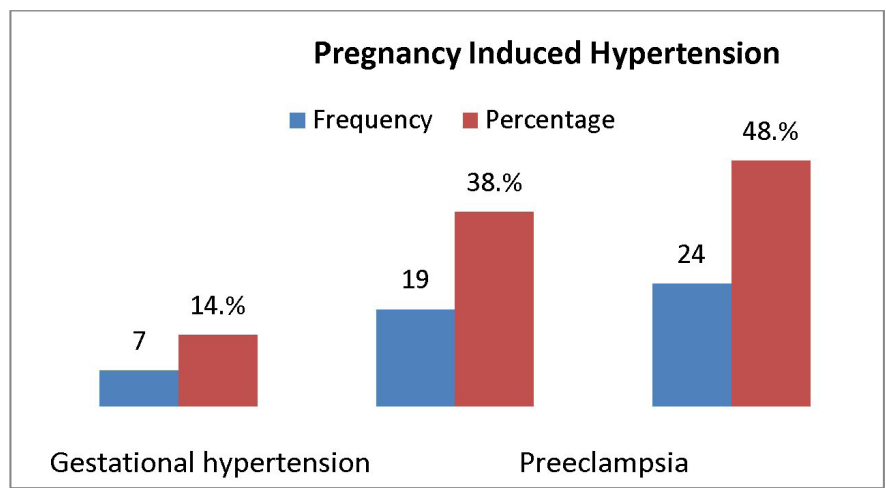

Figure 4

\section{Relation of PIH with Platelet Count}

In this study, moderately low platelet count was seen in $11.76 \%$ of Gestational hypertension, $47 \%$ of pre-eclampsia and $41.17 \%$ of eclampsia and severely low platelet count in $21.4 \%$ preeclampsia and $64.70 \%$ of eclampsia as shown in Fig 5.

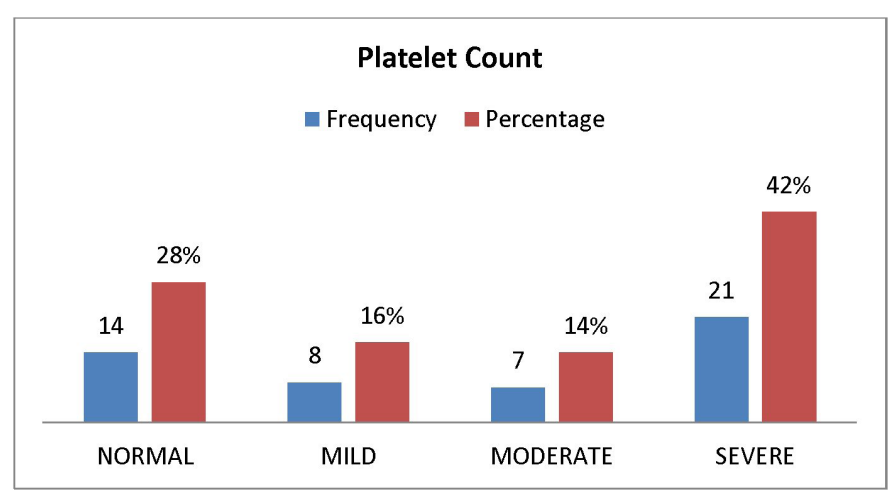

Figure 5 


\section{Mode of Delivery:}

In this study, 54\% cases had vaginal deliveries and $46 \%$ underwent caesarean section which is shown in table I.

\begin{tabular}{|cccccc|}
\hline \multicolumn{3}{|c}{ Vaginal 27 (54 \%) } & \multicolumn{3}{c|}{ Caesarean Section 23(46\%) } \\
\hline & Frequency & Percentage & & Frequency & Percentage \\
\hline SVD & 20 & $74.07 \%$ & $\begin{array}{c}\text { Non progress } \\
\text { of labour }\end{array}$ & 5 & $21.73 \%$ \\
\hline Vacuum & 4 & $14.81 \%$ & $\begin{array}{c}\text { Oligohy- } \\
\text { dramnios }\end{array}$ & 2 & $8.69 \%$ \\
\hline Forceps & 3 & $11.11 \%$ & $\begin{array}{c}\text { Failed } \\
\text { Induction }\end{array}$ & 6 & $26.0 \%$ \\
\hline Total & $\mathbf{2 7}$ & $\mathbf{1 0 0}$ & Total Distress & 10 & $43.47 \%$ \\
\hline
\end{tabular}

Table I : Distribution of cases according to Severity of PIH

\begin{tabular}{|c|c|c|c|c|c|}
\hline $\begin{array}{l}\text { Age group in } \\
\text { years }\end{array}$ & $\begin{array}{c}\text { Gestational } \\
\text { hypertension }\end{array}$ & $\begin{array}{c}\text { PIH } \\
\text { Pre- } \\
\text { eclampsia }\end{array}$ & Eclampsia & Total & $p$ value \\
\hline $15-20$ & $00 \%$ & $\begin{array}{c}7 \\
(36.84 \%)\end{array}$ & $\begin{array}{c}12 \\
(50 \%)\end{array}$ & 19 & \multirow{2}{*}{0.096} \\
\hline $21-26$ & $\begin{array}{c}4 \\
(57 \%)\end{array}$ & $\begin{array}{c}7 \\
(36.84 \%)\end{array}$ & $\begin{array}{c}9 \\
(37.5 \%)\end{array}$ & 20 & \\
\hline $27-30$ & $00 \%$ & $\begin{array}{c}2 \\
(10.5 \%)\end{array}$ & $\begin{array}{c}2 \\
(8.33 \%)\end{array}$ & 4 & \\
\hline $31-40$ & $\begin{array}{c}3 \\
(42.85 \%)\end{array}$ & $\begin{array}{c}3 \\
(15.78 \%)\end{array}$ & $\begin{array}{c}1 \\
(4.16 \%)\end{array}$ & 7 & \\
\hline Total & 7 & 19 & 24 & 50 & \\
\hline
\end{tabular}

$p$ value is 0.096 which is statistically not significant.

\section{Severity of PIH with Gestational age in Weeks}

\begin{tabular}{|c|c|c|c|c|c|}
\hline \multirow{2}{*}{ PIH } & \multicolumn{3}{|c|}{ Gestational Age In Weeks } & \multirow[t]{2}{*}{ Total } & \multirow{2}{*}{$\begin{array}{c}P \\
\text { Value }\end{array}$} \\
\hline & $28-33$ & $34-36$ & $37-42$ & & \\
\hline $\begin{array}{l}\text { Gestational } \\
\text { hypertension }\end{array}$ & $\begin{array}{c}0 \\
(0 \%)\end{array}$ & $\begin{array}{c}3 \\
(27.27 \%)\end{array}$ & $\begin{array}{c}4 \\
(12.12 \%)\end{array}$ & 7 & \multirow{4}{*}{0.039} \\
\hline Pre-eclampsia & $\begin{array}{c}1 \\
(16.66 \%)\end{array}$ & $\begin{array}{c}1 \\
(9.09 \%)\end{array}$ & $\begin{array}{c}17 \\
(51.51 \%)\end{array}$ & 19 & \\
\hline Eclampsia & $\begin{array}{c}5 \\
(83.33 \%)\end{array}$ & $\begin{array}{c}7 \\
(63.63 \%)\end{array}$ & $\begin{array}{c}12 \\
(36.36 \%)\end{array}$ & 24 & \\
\hline Total & 6 & 11 & 33 & 50 & \\
\hline
\end{tabular}

$p$ value is 0.039 which is statistically significant.

\section{Severity of PIH with Platelet Count}

\begin{tabular}{|ccccccc|}
\hline PIH & \multicolumn{3}{c}{ Platelet Count } & Severe & Total & $\begin{array}{c}\mathbf{p} \\
\text { Value }\end{array}$ \\
\hline $\begin{array}{c}\text { Gestational } \\
\text { hypertension }\end{array}$ & $\begin{array}{c}\text { Normal } \\
(33.33 \%)\end{array}$ & $\begin{array}{c}\text { Mild } \\
(30 \%)\end{array}$ & $\begin{array}{c}\text { Moderate } \\
(11.76 \%)\end{array}$ & 0 & 8 & \\
\hline $\begin{array}{c}\text { Pre- } \\
\text { eclampsia }\end{array}$ & 3 & 5 & 8 & 3 & 19 & \\
\hline Eclampsia & 3 & 2 & 7 & 11 & 23 & \\
\hline Total & 9 & 10 & 17 & 14 & 50 & \\
\hline
\end{tabular}

Above shows that severe thrombocytopenia seen in women with preeclampsia and eclampsia.

\section{Distribution of cases according to Platelet Count}

Severity of thrombocytopenia with maternal age

\begin{tabular}{|c|c|c|c|c|c|c|}
\hline \multirow{2}{*}{$\begin{array}{l}\text { Maternal } \\
\text { Age (Years) }\end{array}$} & \multicolumn{4}{|c|}{ Platelet Count } & \multirow{2}{*}{ Total } & \multirow{2}{*}{$\begin{array}{c}p \\
\text { Value }\end{array}$} \\
\hline & Normal & Mild & Moderate & Severe & & \\
\hline $15-20$ & $\begin{array}{c}3 \\
(27.27 \%)\end{array}$ & $\begin{array}{c}4 \\
(40 \%)\end{array}$ & $\begin{array}{c}5 \\
(38.46 \%)\end{array}$ & $\begin{array}{c}7 \\
(43.75 \%)\end{array}$ & 19 & \\
\hline $21-25$ & $\begin{array}{c}7 \\
(63.63 \%)\end{array}$ & $\begin{array}{c}5 \\
(50 \%)\end{array}$ & $\begin{array}{c}4 \\
(30.76 \%)\end{array}$ & $\begin{array}{c}4 \\
(25 \%)\end{array}$ & 20 & \\
\hline $26-30$ & 0 & 0 & $\begin{array}{c}3 \\
(23.07 \%)\end{array}$ & $\begin{array}{c}1 \\
(6.25 \%)\end{array}$ & 4 & 0.280 \\
\hline $31-40$ & $\begin{array}{c}1 \\
(9.09 \%)\end{array}$ & $\begin{array}{c}1 \\
(10 \%)\end{array}$ & $\begin{array}{c}1 \\
(7.69 \%)\end{array}$ & $\begin{array}{c}4 \\
(25 \%)\end{array}$ & 7 & \\
\hline Total & 11 & 10 & 13 & 16 & 50 & \\
\hline
\end{tabular}

Severity of Thrombocytopenia with Maternal Outcome

\begin{tabular}{|c|c|c|c|c|c|c|}
\hline \multirow{2}{*}{$\begin{array}{l}\text { Maternal } \\
\text { Outcome }\end{array}$} & \multicolumn{4}{|c|}{ Platelet Count } & \multirow{2}{*}{ Total } & \multirow{2}{*}{$\begin{array}{c}P \\
\text { Value }\end{array}$} \\
\hline & Normal & Mild & Moderate & Severe & & \\
\hline $\begin{array}{c}\text { No } \\
\text { Complication }\end{array}$ & $\begin{array}{c}13 \\
(92.85 \%)\end{array}$ & 8 & $\begin{array}{c}3 \\
(42.85 \%)\end{array}$ & $\begin{array}{c}9 \\
(42.85 \%)\end{array}$ & 33 & \\
\hline PPH & 0 & 0 & $\begin{array}{c}1 \\
(14.28 \%)\end{array}$ & $\begin{array}{c}4 \\
(19.04 \%)\end{array}$ & 5 & \\
\hline $\begin{array}{l}\text { Abruptio } \\
\text { placenta }\end{array}$ & 0 & 0 & $\begin{array}{c}2 \\
(28.57 \%)\end{array}$ & $\begin{array}{c}1 \\
(4.76 \%)\end{array}$ & 3 & 0.023 \\
\hline $\begin{array}{l}\text { Intracranial } \\
\text { Haemorrhage }\end{array}$ & 0 & 0 & $\begin{array}{c}1 \\
(14.28 \%)\end{array}$ & $\begin{array}{c}2 \\
(9.52 \%)\end{array}$ & 3 & \\
\hline $\begin{array}{c}\text { HELLP } \\
\text { Syndrome }\end{array}$ & $\begin{array}{c}1 \\
(7.14 \%)\end{array}$ & 0 & 0 & $\begin{array}{c}5 \\
(23.80 \%)\end{array}$ & 6 & \\
\hline Total & 14 & 8 & 7 & 21 & 50 & \\
\hline
\end{tabular}

Table above shows more cases of PPH and HELLP syndrome are seen in pregnant women with severe thrombocytopenia.

\section{Severity of Thrombocytopenia with Fetal Outcome}

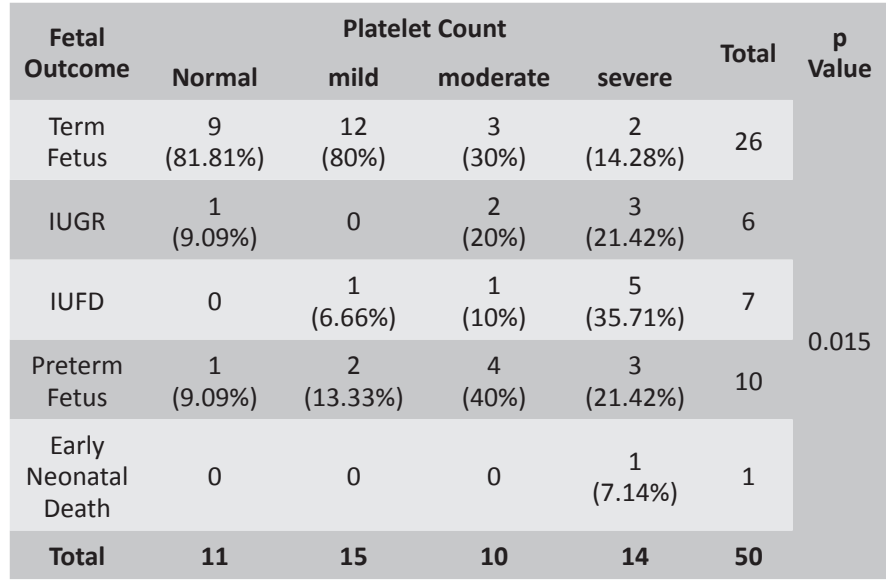

Table VII 
Table above shows that IUGR, IUFD and Early neonatal death are mainly seen in women with severe thrombocytopenia.

\section{DISCUSSION}

Hypertensive disorders which include preeclampsia/ eclampsia represent a significant proportion of maternal deaths worldwide. Such deaths account 9.1\%, 9.1\% and 25.7\% in SubSaharan Africa, South Asia, and Latin America respectively. ${ }^{19} \mathrm{In}$ Nepal, maternal death due to eclampsia accounts for $14 \% .^{20}$ Nepal maternal mortality and morbidity study 2008-09 showed that preeclampsia/eclampsia is the second most common cause of maternal mortality. ${ }^{21}$ Incidence of Pre-eclampsia/ eclampsia in developing countries is $0.94 \%$ to $1.8 \%{ }^{22}$

Whereas incidence is $2.3 \%$ in this study. As regards the age of the women, in this study majority of the women belongs to age group $21-25(40 \%)$ followed by $15-20(38 \%)$ with mean age $23.18 \pm 5.45$.This is similar to the study done by Rahim $R$ $(2010)^{23}$ and Rabia Prabin Sidiqui $(2015)^{24}$ with mean age 23.12 and $23.45 \pm 3.25$ respectively.

In this study, maximum number of women $62 \%$ constituted primigravidas, only $38 \%$ were multigravidas that is similar to study done by Nirmala T( 2015) ${ }^{25}$, Feroza Sultana (2015) $)^{26}$ and Shaiza Riaz et al(2011) $)^{27}$ where $61 \%, 63 \%$ and $60 \%$ cases women affected were primigravidas respectively.

In this study, out of 50 cases, 33 (66\%) cases were at term (3742 weeks of gestation), $11(22 \%)$ at $34-36$ weeks of gestation and $6(12 \%)$ are at $28-33$ weeks of gestation with mean gestational age is $36.38 \pm 3.17$, similar result were observed by Chaudhary $\mathrm{P}(2003)^{27}, 72.34 \%$ cases were at term whereas relatively more cases occurred before 37 completed weeks in the study done by Douglas L A. (1994)..$^{28}$ In this study, eclampsia cases were found more i.e. $48 \%$ followed by pre-eclampsia $38 \%$ and Gestational hypertension $14 \%$. In a study from Bhopal by Anand and Kirshnanand et $a^{29}$ majority of the cases had preeclampsia (66.36\%) and the rest eclampsia (33.64\%). In this study, moderately low platelet count was seen in $11.76 \%$ of Gestational Hypertension, $47 \%$ of pre-eclampsia and $41.17 \%$ of eclampsia and severely low platelet count in $21.4 \%$ preeclampsia and $64.70 \%$ of eclampsia. Which is similar to study by Khan A et al $(2014)^{30}$ with lowered platelet count $29.31 \%$ in pre-eclampsia and $44.44 \%$ in eclampsia.

In this study, $54 \%$ cases had vaginal deliveries and $46 \%$ underwent caesarean section, which is comparable to study done by Kuljit Kaur (2014) ${ }^{31}$ where $35 \%$ had caesarean section.

In this study, Fetal Distress and Non Progress of Labour were the most common causes of caesarean sections i.e. (43.47\%) and $(21.73 \%)$ which is comparable to the study done by Singhal et al (2009), which reported (32\%) of caesarean sections out of their total 100 cases of pre-eclampsia and fetal distress was the most common indication of caesarean section (59.28\%) followed by Non Progress Of Labour $(12.5 \% \text {. })^{32}$
In this study, the most common maternal complication was HELLP syndrome (12\%) followed by PPH (10\%), Abruptio Placenta (6\%) and Intracranial hemorrhage due to DIC (6\%), similar to study done by Meshram et al (2014) $)^{33}$ who observed HELLP syndrome in (10.6\%) cases, PPH in (8.5\%) and DIC in (3\%) cases. In this study (54\%) babies have birth weight $\leq$ $2.5 \mathrm{~kg}$, (12\%) with IUGR, (14\%) with IUFD, (20\%) Premature

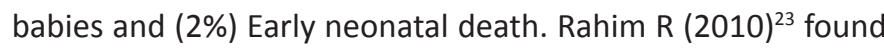
(74.28\%) babies with low birth weight in patient with low platelet count. A study by Shahla K (2014) $)^{34}$ found (17.3\%) babies born to hypertensive mother had birth weight less than $2500 \mathrm{gm}$ in (17.3\%), (5.5\%) had birth weight less than $1500 \mathrm{gm}$, IUGR in (9.8\%) cases, IUFD in (5.5\%) cases and neonatal death in $(6.1 \%)$ cases.

\section{LIMITATIONS}

- As the pathophysiology of PIH is complex and elusive so exact prediction of prognosis of disease still remains a challenge, there is no single marker or lab investigation which can strongly predict the prognosis of disease. So future research in this field is necessary.

- Sample size is small to give the exact representation of the general population.

\section{CONCLUSION}

HELLP syndrome complicates almost $20 \%$ of women with severe pre-eclampsia and eclampsia. Best markers to be followed are maternal platelet count and lactate dehydrogenase level. Prompt recognition and timely initiation of therapy are vital to ensure best outcome for both mother and fetus. Up to $50 \%$ of patients with pre-eclampsia /eclampsia developed thrombocytopenia. Severity is generally proportional to the underlying disease. In this study, severe thrombocytopenia contributed to poor maternal outcome with significant $P$ value of 0.023 . As well as fetal outcome was affected by increasing severity of thrombocytopenia with significant $p$ value of 0.015 . Hence it emphasizes on the importance of early recognition of thrombocytopenia for management of PIH ensuring safety to both baby and mother.

As PIH is an important complication of pregnant mother in developing countries. In Nepal maternal mortality due to eclampsia is $14 \%$ and second most common cause of maternal mortality and morbidity. Though prognosis of $\mathrm{PIH}$ is unpredictable, there are several laboratory investigations which were done in different studies like platelet aggregation test, platelet reactivity, serum level of LDH and transaminase, coagulation profile (BT, CT, PT aPTT) Platelet indices (MPV, Platelet Distribution width, platelet count) which predict the prognosis of disease. Besides that comparison study between platelet count and platelet indices can also be done to predict prognosis of PIH. Special focus should be given regarding health education and emphasizing regular ANC visits, correction 
of anemia and infection, proper balance diet, calcium and micronutrient supplementation. In addition socio-economic status should be improved. As emphasized earlier, out of many tests, platelet estimation method is reliable, rapid, cheaper, and simple lab method which does not require sophisticated lab setup, highly skilled manpower. Prognosis of diseases could be monitored by measuring platelet count and level of platelet count can predict the severity of PIH. Therefore assessment of platelet count has special place in management of PIH.

\section{REFERENCES}

1. Zamorski M A, Green L A. NHBPEP Report on High Blood Pressure in Pregnancy: A Summary for Family physicians. Am Fam Physician. 2001 Jul15; 64(2): p263-71.

2. Sibai B M. Hypertension in pregnancy. Clinical Obstet Gynecol, 1999:p421-36.

3. Sibai B M. Hypertension in pregnancy. In S.G. Gabbe, J.R. Niebyl, J.L. Simpson editors. Obst. Normal and Problem of Pregnancies. $3^{\text {rd }}$ Ed, New York: Churchill Livingstone; 1996;p 935-991.

4. Vince G S, Starkey P M, Austgulen R, Kwiatowski D, Redman CWG. Interleukin-6, tumour necrosis factor and soluble tumour necrosis factor in women with preeclampsia. $\mathrm{Br} J$ Obstet Gynaecol 1995; 102: p 20-5.

5. Nyfløt LT, Ellingsen L, Yli BM, Øian P, Vangen S. Maternal deaths from hypertensive disorders: lessons learnt. Acta Obstet Gynecol Scand 2018; 97:976-987

6. Khan K S, Wojdyla D, Say $L$ et al. WHO analysis of cause of maternal death: systemic review.Lancet.2006; 367:p1066-74.

7. Cunningham F G, Norman F G, Kerneth J, Gilstrap L C, Hauth J C, Wenstom K D. Hypertensive disorders in pregnancy. In A.Seilis, S.R. Noujaim, K Davis, editors. Williams Obstetrics. International Edn, 21st Edn, NewYork : McGraw Hill; 2001; p 567-618.

8. Sibai BM. Diagnosis and management of gestational hypertension and preeclampsia. ObstetGynecol 2005; 105:p 402-10.

9. Vijaya C, Lekha M B, Shetty A et al. Evaluation of Platelet Counts and Platelet Indices and their Significant Role in Pre-eclampsia and Eclampsia. Journal of Evolution of Medical and Dental Sciences 2014; Vol. 3, Issue 12, March 24; p 3216-19

10. Sibai B, Dekker G. and Kupferminc M. (2005): Preeclampsia; Lancet; 365: p 785-99

11. Laki K.Our ancient heritage in blood clotting and some of its consequences. Annals of the New York Academy of Sciences; 1972; 202: p 297-307.

12. Ross D W, Ayscue L H, Watson J, Bentley S A. Stability of hematologic parameters in healthy subjects. Intraindividual versus interindividual variation. American journal of clinical pathology; 1988; 90 (3): p262-7.

13. Tygart S G, McRoyan D K, Spinnato J A, McRoyan C J, Kitay D Z. Longitudinal study of platelet indices during normal pregnancy. Am J Obstet Gynecol 1986; 154: p 883-87.
14. Sibai B M. Hypertension in pregnancy. In S.G. Gabbe, J.R. Niebyl, J.L. Simpson editors. Obst. Normal and Problem of Pregnancies. $3^{\text {rd }}$ Ed, New York: Churchill Livingstone; 1996; p 935-991.

15. Vince G S, Starkey P M, Austgulen R, Kwiatowski D, Redman CWG. Interleukin-6, tumour necrosis factor and soluble tumour necrosis factor in women with preeclampsia. $\mathrm{Br} J$ Obstet Gynaecol 1995; 102: p 20-5.

16. Wein Stein L. Syndrome of hemolysis, elevated liver enzyme, low platelet count; a severe consequence of hypertension in pregnancy. Am J Obstet and Gynaecol 1982; 142:p 159.

17. Varol E, Akcay S, Icli A, Yucel H, Ozkan E, Erdogan D et al. Mean platelet volume in patients with prehypertension and hypertension. Clin Hemorheol Microcirc. 2010;45:p67-72.

18. Stekkinger E, Zandstra M, Peeters L L, Spaanderman M E. Early onset preeclampsia and the prevalence of postpartum metabolic syndrome. Obstet Gynecol. 2009; 114:p1076-1084.

19. Khan K S, Wojdyla D, Say L, Gulmezoglu A M, Van Look P F. WHO analysis of causes of maternal death: a systematic review. Lancet. 2006; 367(9516): p 1066-74.

20. Vaidya A, Shakya B. Overview of eclampsia at poropakar maternity and women's hospital. 52 anniversary maternity hospital 2011; 8 .

21. Pradhan A, Suvedi B K, Barnett S, Sharma S K, Puri M, Poudel P, et al. Nepal maternal mortality and mortality study 2008/2009. Kathmandu, Nepal: Family health division, department of health services, ministry of health and population; 2010.

22. Chhahra S, Kakani A. Maternal mortality due to eclamptic and noneclamptic hypertension disorder. A challaye.J obstet Gynaecol.2007;21(1):p25-9.

23. Rahim R, Nahar K, Khan I A et al. Platelet count in 100 cases of pregnancy induced hypertension. Mymensingh Med J. 2010 Jan; 19(1):p 5-9.

24. Siddiqui R P, Chandrakar K, Varma R, Shreevastava S. Study on platelet indices in pregnancy induced hypertension. Journal of Evidence Based Medicine and Health care 2015;2(44): p 803540.

25. Nirmala T, Vani B R, Srinivasa M, Kumar B K, RL Geetha , L $P$ Kumar. Study Of Platelet Indices In Pregnancy Induced Hypertension (PIH). Indian Journal of Pathology and Oncology; Jan -Mar 2015;2(1):p 25-30.

26. Sultana F, Parthiban $R$, Shariff $S$. Thrombocytopenia in pregnancy induced hypertension. J Med Sci Health 2015;1(2):p 19-24.

27. Riaz S, Habib S, Jabeen A. Frequency of maternal mortality and morbidity in pregnancy-induced hypertension. J Ayub Med Coll Abbottabad 2011;23:p61-3.

28. Douglas L A. Redman CWG. Eclampsia in the United Kingdom. British medical journal.1994 Nov.26:309:p1395-1400.

29. Anand S, Kirshnanand. Perinatal outcome in growth retarded babies born to normotensive and hypertensive mothers: A prospective study. People's J Sci Res 2012;5: p 24-8. 
30. Khan A, Fahim A, Qureshi A, Nizamani G S, Azmi M A. Pregnancy induced hypertension: assessment of prognostic value of platetet count in women with varying degree. Profession Med J 2014;21(3):p436-40.

31. Kaur K, Shrivastav R D, Rahatgaonkar V, Bhosale U T. Study of Fetal and Maternal Outcome in Eclampsia .IJRTST. Volume 11, Issue 1, 2014:p 42-4

32. Singhal SR, Deepika, Anshu, Nanda S. Maternal and perinatal outcome in severe pre-eclampsia and eclampsia. South Asiafedderation of obstetrics and Gynaecology 2009;1:p 25-8.

33. Yaprak E U, Kezban D, Llgn T, Yusuf U, Mehmet M M, AyfleK et al. Evaluation of Hemoglobin and Platelet Levels in Mild, Int J Pharm Bio Sci 2015 Jan; 6(1):p 854 - 9.

34. Shahla K, Soheila D, Lotfi M, Mohammad A. Study of the prevalence of hypertension and complication of hypertension disorder in pregnancy.OJPM; vol.04;No 11;Article Id 51671:p7.

35. Parnas M, Sheiner E, Shoham-Vardi I, Brustein E, Yermiahu T, Levi In et al. Moderate to severe thrombocytopenia during pregnancy. Eur J Obstet Gynecol Reprod Biol. 2006; 128: p163 - 8.

36. Polanowska-Grabowska R, Sanghamitra R, Gear ARL. Adhesion efficiency, platelet density and size. Br J Haematol. 1992;82:p 715-720.

37. Ganzevoort W, Rep A, Bonsel G J, Vries J I de, Wolf H. Plasma volume and blood pressure regulation in hypertensive pregnancy. J Hypertens. 2004;22:p1235-1242. 